University of Nebraska - Lincoln

DigitalCommons@University of Nebraska - Lincoln

Renewed Selection for Heat Loss in Mice: Direct Responses and Correlated Responses in Feed Intake, Body Weight, Litter Size, and Conception Rate

\author{
J. M. McDonald \\ University of Nebraska-Lincoln \\ Merlyn K. Nielsen \\ University of Nebraska-Lincoln, mnielsen1@unl.edu
}

Follow this and additional works at: https://digitalcommons.unl.edu/animalscifacpub

Part of the Animal Sciences Commons

McDonald, J. M. and Nielsen, Merlyn K., "Renewed Selection for Heat Loss in Mice: Direct Responses and Correlated Responses in Feed Intake, Body Weight, Litter Size, and Conception Rate" (2007). Faculty Papers and Publications in Animal Science. 511.

https://digitalcommons.unl.edu/animalscifacpub/511

This Article is brought to you for free and open access by the Animal Science Department at DigitalCommons@University of Nebraska - Lincoln. It has been accepted for inclusion in Faculty Papers and Publications in Animal Science by an authorized administrator of DigitalCommons@University of Nebraska - Lincoln. 


\title{
Renewed selection for heat loss in mice: Direct responses and correlated responses in feed intake, body weight, litter size, and conception rate ${ }^{1}$
}

\author{
J. M. McDonald and M. K. Nielsen ${ }^{2}$ \\ Department of Animal Science, University of Nebraska, Lincoln 68583-0908
}

\begin{abstract}
Divergent selection in mice was renewed in 3 independent replicates for high $(\mathrm{MH})$ and low (ML) heat loss. An unselected control (MC) was maintained in all replicates. Heat loss was measured for individual male mice for $15 \mathrm{~h}$, overnight in direct calorimeters. After 16 initial generations of selection followed by 26 generations of relaxed selection, divergent selection resumed for 9 generations. The realized selection applied was very close to the maximum possible selection according to the criteria and protocol. Selection differentials were greater for high than for low selection due to greater variation in the $\mathrm{MH}$ line. When corrected for SD, standardized selection differentials were similar for $\mathrm{MH}$ and ML selection. Unintended selection in MC was negligible. Realized heritability for divergence was $0.14 \pm 0.01$, which was considerably
\end{abstract}

less than that realized during the initial generations of selection $(0.28 \pm 0.03)$. Realized heritabilities for $\mathrm{MH}$ selection $(0.16 \pm 0.05)$ and for ML selection $(0.07 \pm 0.06)$ were less, especially for ML selection, than were observed in the earlier generations. The difference in heat loss between $\mathrm{MH}$ and ML males was $55.7 \%$ of the MC mean at generation 51, compared with a difference of $53.6 \%$ in generation 15; this difference had decreased to $34.4 \%$ at the end of the relaxed selection (generation 42). For feed intake between 8 and $11 \mathrm{wk}, \mathrm{MH}$ and $\mathrm{ML}$ males differed by $34.0 \%$ of the MC mean by the end of the selection process. Body weight at $12 \mathrm{wk}$ for $\mathrm{MH}$ and ML males was less than for MC males. Litter size response was positively related to the heat loss response. Conception rate was poorer in $\mathrm{MH}$ matings than in MC and ML matings.

Key words: conception rate, feed intake, heat loss, litter size, mice, renewed selection

(02007 American Society of Animal Science. All rights reserved.

J. Anim. Sci. 2007. 85:658-666 doi:10.2527/jas.2006-465

\section{INTRODUCTION}

Maintenance feed energy requirements of animals represent large economic inputs in livestock production, and they are more variable than the costs above maintenance for feed per unit of production (i.e., milk production, growth, etc.). As animals metabolize food, energy that is not stored in a product is lost in the form of heat. Nielsen et al. $(1997 \mathrm{a}, \mathrm{b})$ showed that it is possible to change maintenance requirements in mice through selection using total heat loss as the indicator trait. Existence of variation in heat loss made it possible to select animals based on their heat production/loss as a method to produce more efficient animals. Mousel et al. (2001) demonstrated a large correlated response in

\footnotetext{
${ }^{1}$ A contribution of the University of Nebraska Agricultural Research division, Lincoln. Journal Series No. 15255. This research was supported in part by funds provided through the Hatch Act.

${ }^{2}$ Corresponding author: mnielsen1@unl.edu

Received July 14, 2006.

Accepted October 17, 2006.
}

locomotor activity, and Eggert and Nielsen (2006) reported no differences in partial efficiencies for growth due to selection. McDonald and Nielsen (2006) reported a correlated response in lactation yield resulting from a positive genetic correlation with the maintenance requirement.

Nielsen et al. (1997a,b) showed that the initial selection practiced for heat loss in mice was effective through 15 generations in the high (MH) and low (ML) directions. Selection for heat loss produced a divergence between the MH and ML lines (MH - ML) of 20.6\% relative to the control (MC) mean for maintenance feed costs, with the ML lines consuming the least. After the initial 16 generations, selection was suspended, and the effective population size was expanded in all lines to reduce the rate of inbreeding. At generation 42, heat measurements and selection were resumed following the initial protocol for the $\mathrm{MH}, \mathrm{ML}$, and $\mathrm{MC}$ lines.

The objective of this study was to report the direct response to renewed selection for heat loss in male mice from generations 42 through 51, as well as the correlated responses in feed intake, male BW, litter size, and conception rate. 


\section{MATERIALS AND METHODS}

\section{Experimental Animals}

All procedures involving animals were approved by the University of Nebraska-Lincoln Institutional Animal Care and Use Committee. The lines of mice used for this study have been previously described by Nielsen et al. (1997a) and represent the outcomes after divergent selection for heat loss. All lines were originally derived from a base population resulting from a 4-way cross of 4 outbred lines. There were 3 criteria for selection: $\mathrm{MH}=$ selection for high heat loss, $\mathrm{ML}=$ selection for low heat loss, and MC = no selection. Breeders for each new generation were chosen from the previous generation's 16 litters in a line-replicate.

After the initial selection for 16 generations, selection was suspended, and the lines were maintained through generation 41 using breeders that equally represented 26 litters per line-replicate-generation to reduce the rate of inbreeding. The experiment was carried out in 3 replicates, each separated by a 5 -wk interval. Three lines with 3 replicates yielded 9 unique selection lines with a generation interval of $15 \mathrm{wk}$. For this study, selection began again within the heat loss lines; thus, line sizes of only 16 litters began again at generation 42 and continued through generation 50 , with the final response measured in generation 51. Mean inbreeding coefficients were similar across lines and replicates and averaged approximately $0.16,0.28$, and 0.36 at generations 16,42 , and 51 , respectively.

\section{Heat Loss and Feed Intake Measurements}

Ten direct, gradient-layer, individual-animal calorimeters (Model 0601-S, gradient-layer Seebeck envelope, Thermonetics Corporation, San Diego, CA) were used to obtain single heat loss measurements (kcal. $\mathrm{kg}^{-0.75} \cdot \mathrm{d}^{-1}$ ) from only male animals. Animals ranged from 9 to $11.5 \mathrm{wk}$ of age at the time of measurement. The design of the direct, gradient-layer calorimeters and the setup of the data-acquisition system were described in Nielsen et al. (1997a).

Individual mice were weighed and placed in stainless steel cages with approximately $3.5 \mathrm{~g}$ of feed. Each cage was placed in 1 of the 10 calorimeters, and the lids were used to seal the units. Mice are nocturnal animals; therefore, data were collected overnight for $15 \mathrm{~h}$. Within each replicate, heat loss measurements occurred over a 3-wk period. During this period, all of the males from the $\mathrm{MH}$ and ML lines were measured (between 75 and 80 in each line-replicate), as were 25 to 35 males from the MC line.

During this same time period, feed intake was collected on male littermate cages, and the mice were housed in plastic cages (Ancare Corp., Waupaca, WI). Feed intake measurements began at 8 wk of age and were calculated as the amount of feed that disappeared over a period of $1 \mathrm{wk}$, divided by the number of animals in the cage. Feed intake measurements continued through 11 wk of age. Final feed intake data were totaled for the 3-wk period and expressed as daily grams of feed per unit of metabolic BW $\left(\mathrm{kg}^{0.75}\right)$. Throughout the feed intake trial, mice were given ad libitum access to water and were fed a maintenance diet (Teklad 8604: $24 \% \mathrm{CP}, 4 \%$ crude fat, $4.5 \%$ crude fiber, and $3.93 \mathrm{kcal}$ of GE/g of feed, Harlan Teklad, Madison, WI). Individual BW were recorded on the first and last days of the 3-wk trial and then averaged over all mice in that line-replicate.

\section{Selection of Breeder Males and Matings}

Once individual heat loss and cage feed intake measurements were taken, the heat loss data were sorted, and males were selected to become breeders at $12 \mathrm{wk}$ of age. In the MH lines, the 16 males with the greatest heat loss were chosen to produce the next generation. The opposite was true for the ML line. Matings were designed to place 1 male with 2 full-sibling females that had the lowest available relationship with that male to avoid excessive inbreeding within the lines. Males were selected based on their own individual heat loss estimate; thus, some MH and ML litters produced multiple males that were selected for breeding, whereas some litters produced none. Two extra males ranking \#17 and \#18 on the heat loss criterion in the $\mathrm{MH}$ and $\mathrm{ML}$ lines were also chosen and mated to 2 females. These males provided extra litters for the $\mathrm{MH}$ and $\mathrm{ML}$ lines in case one or more of the top 16 males failed to produce litters for the next generation.

In the MC line, 16 males ( 1 randomly chosen from each of the 16 litters) were mated to 2 females each, again using a pair of full sisters. A combination of 2 , circular mating designs was used that showed accumulation of inbreeding similar to that of the $\mathrm{MH}$ and $\mathrm{ML}$ lines. A spare (17th) male was also mated to 2 females in the event that 1 of the $16 \mathrm{MC}$ males failed to produce a litter. The animals remained in the mating cages for $16 \mathrm{~d}$ and were given ad libitum access to feed (Teklad diet 8604) and water.

Cumulative selection differentials (CSD) for $\mathrm{MH}$, MC, and ML for generations 43 through 51 were calculated as:

$$
\mathrm{CSD}_{\mathrm{n}}=0.5 \mathrm{M}_{\mathrm{n}-1}+0.25 \sum_{i=42}^{\substack{n-2 \\ \text { for } \\ n \geq 44}}\left(\mathrm{M}_{\mathrm{i}}+\mathrm{F}_{\mathrm{i}}\right) \text {, }
$$

where $\mathrm{n}$ is the number of generations of selection completed, and $\mathbf{M}$ and $\mathbf{F}$ are male and female selection differentials. Male selection differentials are calculated as the sum of the deviations of selected male records from the generation-replicate-line mean $\left(\mathrm{P}_{\mathrm{i}}-\mu\right)$, weighted by the number of sons that had records, and divided by the number of males measured in the sons' generation $(\mathrm{N})$ : 


$$
\mathrm{M}=\sum_{i=1}^{16}\left(\mathrm{P}_{\mathrm{i}}-\mu\right)(\text { number of sons }) /(\mathrm{N}) .
$$

"Female" selection differentials were calculated in the same manner as the male differentials, except that deviations from the generation-replicate-line mean were weighted by the number of grandsons (with records) through daughters rather than the number of sons. Here, $\mathrm{N}$ represented the number of males measured in the grandsons' generation:

$$
\mathrm{F}=\sum_{i=1}^{16}\left(\mathrm{P}_{\mathrm{i}}-\mu\right)(\text { number of grandsons }) /(\mathrm{N}) .
$$

\section{Littering and Selection of New Litters}

After the 16-d mating period, females were transferred to individual littering cages. Dams were given a handful of Tek-Fresh nesting material (Harlan Teklad) to build littering nests, ad libitum access to a lactation diet throughout the littering and lactation period (Teklad 8626: $20 \% \mathrm{CP}, 10 \%$ crude fat, $2 \%$ crude fiber, and $4.25 \mathrm{kcal}$ of GE/g, Harlan Teklad), and ad libitum access to water. Within $24 \mathrm{~h}$ of birth, the date, number of pups of each sex, and total number of fully formed pups (alive or dead) were recorded. With a $100 \%$ conception rate, we expected 36 litters in each of the $\mathrm{MH}$ and ML lines, and 34 litters in the MC line. If litters were larger than 8 live pups at birth, they were standardized to 8 total pups with a desired sex ratio of 5 males and 3 females.

Litters were selected based on the sex ratio and birth date and identified according to the rank of the sire. The sex ratio of 5 males and 3 females was not always obtained; therefore, litters with less-desirable sex ratios were used. Sixteen litters were chosen to contribute males for calorimeter measurements in the next generation, and litters whose sires ranked \#17 and \#18 were selected as spares. When the pups reached $10 \mathrm{~d}$ of age, their toes were clipped for identification and the dam and litter were placed in clean cages. Litter size was measured as the total number of live and dead fully formed pups at birth. Conception rate was the fraction of females exposed to breeding that had litters.

\section{Weaning}

In all replicates, mice were weaned at $21 \mathrm{~d}$ of age. At this time, males and females were placed in separate cages by full-sib family. Generally, no more than 5 mice were placed in each cage. Males and females were given ad libitum access to a maintenance diet (Teklad 8604) and water.

\section{Statistical Analysis}

Realized cumulative selection differentials for $\mathrm{MH}$ and $\mathrm{ML}$, and divergence of the response (difference in means, MH - ML) for heat loss were regressed on gener- ation number within each replicate. Divergence of the response (MH - ML) was regressed on the difference of the realized cumulative selection differential $(\mathrm{MH}-$ ML) to obtain heritability estimates for each replicate. Responses in the upward and downward directions (MH - MC and ML - MC, respectively) were regressed on differences in cumulative selection differentials $(\mathrm{MH}-$ $\mathrm{MC}$ and $\mathrm{ML}-\mathrm{MC}$, respectively) within each replicate. For all regressions, estimates were averaged across all 3 replicates, and empirical SE were calculated for the mean regressions and tested with 2 degrees of freedom.

Male feed intake calculation yielded average grams consumed per unit of metabolic weight per day ( $g$. $\mathrm{kg}^{-0.75} \cdot \mathrm{d}^{-1}$ ) in each line-replicate from 8 to $11 \mathrm{wk}$ of age. Divergence of the response (MH - ML), as well as the responses in the high and low direction $(\mathrm{MH}-\mathrm{MC}$ and ML - MC, respectively) for feed intake adjusted for mean metabolic weight were regressed on generation number for each replicate. Regression estimates were averaged across replicates, and empirical SE were calculated.

Litter size means and conception rates were fitted to the model

$$
\begin{aligned}
\mathrm{Y}_{\mathrm{ijkl}}= & \text { rep }_{\mathrm{i}}+\text { line }_{\mathrm{j}}+\text { generation }_{\mathrm{k}}+(\text { rep } \times \text { line })_{\mathrm{ij}} \\
+(\mathrm{rep} & \times \text { generation })_{\mathrm{ik}}+(\text { line } \times \text { generation })_{\mathrm{jk}} \\
& +(\text { rep } \times \text { line } \times \text { generation })_{\mathrm{ijk}}+\mathrm{e}_{\mathrm{ijk} \mathrm{kl}},
\end{aligned}
$$

where $\mathrm{Y}_{\mathrm{ijkl}}$ is the mean litter size or the conception

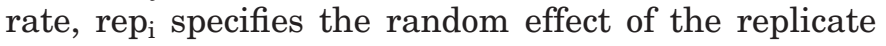
(replicate 1,2 , or 3 ), line $e_{j}$ is the fixed effect of the line $(\mathrm{MH}, \mathrm{ML}$, or $\mathrm{MC})$, generation $\mathrm{k}_{\mathrm{k}}$ is the fixed effect of the generation (generation 42 through 51); the remaining terms are the interaction effects and residual error to complete the model. Contrasts of $\mathrm{MH}$ vs. $\mathrm{ML}$ and $\mathrm{MH}$ $+\mathrm{ML}) / 2$ vs. MC were carried out to test the effect of selection and asymmetry of the response.

\section{RESULTS AND DISCUSSION}

\section{Selection Applied}

Cumulative intended, realized, and standardized realized selection differentials after 9 generations of resumed selection for high and low heat loss are given in Table 1. Realized cumulative selection differentials were similar to intended cumulative selection differentials. The proportion of cumulative selection achieved ranged from 99 to $102 \%$ in $\mathrm{MH}$ and ML replicated lines, and averaged $100 \%$ across all selection lines. This shows that the top 16 ranking males from each generation-replicate-line were generally successful at producing sons and grandsons to be measured for heat loss in subsequent generations. Although the mean observed here is slightly greater than the average of $98 \%$ selection achieved reported for the first 15 generations of these lines, Nielsen et al. (1997a) observed a similar range of 97.3 to $100 \%$ selection achieved. 
Table 1. Cumulative intended and realized (both as kcal $\left.\mathrm{kg}^{-0.75} \cdot \mathrm{d}^{-1}\right)$ and standard realized selection differentials, and the averages across all 3 replicates (Rep)

\begin{tabular}{lccc}
\hline \hline $\begin{array}{l}\text { Line }{ }^{1} \text { and } \\
\text { replicate }\end{array}$ & $\begin{array}{c}\text { Cumulative } \\
\text { intended }\end{array}$ & $\begin{array}{c}\text { Cumulative } \\
\text { realized }\end{array}$ & $\begin{array}{c}\text { Cumulative } \\
\text { standard } \\
\text { realized }\end{array}$ \\
\hline MH Rep 1 & 93.36 & 92.51 & 5.35 \\
MH Rep 2 & 83.71 & 85.78 & 5.79 \\
MH Rep 3 & 97.12 & 97.04 & 5.24 \\
MH mean & 91.40 & 91.78 & 5.46 \\
MC Rep 1 & 0.00 & -1.43 & -0.10 \\
MC Rep 2 & 0.00 & -3.42 & -0.23 \\
MC Rep 3 & 0.00 & -1.37 & -0.02 \\
MC mean & 0.00 & -2.07 & -0.12 \\
ML Rep 1 & -54.61 & -54.84 & -4.89 \\
ML Rep 2 & -53.05 & -54.28 & -5.30 \\
ML Rep 3 & -54.45 & -54.61 & -4.92 \\
ML mean & -54.04 & -54.75 & -5.04 \\
\hline
\end{tabular}

${ }^{1} \mathrm{MH}=$ High heat loss selection; $\mathrm{MC}=$ no intentional selection; and $\mathrm{ML}=$ low heat loss selection.

Realized cumulative selection differentials ranged from 83.71 to $97.12 \mathrm{kcal} \cdot \mathrm{kg}^{-0.75} \cdot \mathrm{d}^{-1}$ in the $\mathrm{MH}$ lines and averaged 91.40. The ML cumulative selection differentials ranged from -54.61 to $-53.05 \mathrm{kcal} \cdot \mathrm{kg}^{-0.75} \cdot \mathrm{d}^{-1}$ and averaged -54.04 . Realized cumulative selection differentials, adjusted by generation-line-replicate SD, ranged from 5.24 to 5.79 in the $\mathrm{MH}$ lines and averaged 5.46. A range of -5.30 to -4.89 was observed in the $\mathrm{ML}$ lines, and ML had an overall average of -5.04. Because variation was much greater in the MH than in the ML lines, standardized selection differentials were more similar comparing $\mathrm{MH}$ to ML selection than were the unstandardized selection differentials. Realized cumulative differentials were calculated for the MC to determine if selection had unintentionally occurred in these lines. Realized cumulative differentials ranged from -3.42 to $-1.37 \mathrm{kcal} \cdot \mathrm{kg}^{-0.75} \cdot \mathrm{d}^{-1}$ and averaged -2.07 , whereas standardized realized differentials ranged from -0.23 to -0.02 and averaged -0.12 in the MC lines. Thus, unintended selection was negligible.

Normality of the heat loss distribution was tested in the $\mathrm{MH}$ and ML lines by analyzing residuals from the replicate-generation means of each line with a ShapiroWilk test (Shapiro and Wilk, 1965). In the MH line, normality was rejected $(P=0.01)$; skewness and kurtosis coefficients were -0.2197 and 1.3774 , respectively. This demonstrated that the distribution of $\mathrm{MH}$ heat loss measurements was slightly skewed to the right and was much taller than a normal distribution. In the ML line, normality was also rejected $(P<0.01)$; skewness and kurtosis coefficients were 0.0853 and 1.0845 , respectively. The distribution of heat loss measurements in the ML line was clearly skewed to the left and was also taller than a normal distribution. Distributions with these shapes explain why the standardized selection differentials were greater for the $\mathrm{MH}$ selection than the ML selection, even though similar numbers of animals were measured and selected in both lines.

Regressions of realized cumulative selection differentials and realized standardized cumulative selection differentials on generation number are presented in Table 2. Regressions on generation number ranged from 10.57 to 12.22 in the $\mathrm{MH}$ and -6.92 to -6.59 in the ML. Averaged across all 3 replicates, the regressions were $11.48 \pm 0.49$ and $-6.74 \pm 0.10$ in the $\mathrm{MH}$ and $\mathrm{ML}$, respectively. The cumulative selection differentials for $\mathrm{MH}$ selection were approximately $70 \%$ greater than the cumulative selection differentials for ML selection. However, cumulative selection differentials for $\mathrm{MH}$ selection realized by Nielsen et al. (1997a) were only $40 \%$ greater than the differentials for ML selection.

Regressions of realized standardized cumulative selection differentials on generation number ranged from 0.65 to 0.69 for $\mathrm{MH}$ and from -0.66 to -0.61 for ML. This range is identical to the range of 0.65 to 0.69 for $\mathrm{MH}$ and very similar to -0.65 to -0.63 for $\mathrm{ML}$, as observed by Nielsen et al. (1997a) for the first 15 generations of selection for heat loss in these lines.

\section{Response in Heat Loss over 9 Generations}

A graphical representation of mean heat loss (kcal$\mathrm{kg}^{-0.75} \cdot \mathrm{d}^{-1}$ ) estimates for the MH, ML, and MC lines for each generation of initial and renewed selection (generations 0 to 15 and 42 to 51) averaged across all 3 replicates is shown in Figure 1. Heat loss means for 9 generations of renewed selection are listed in Table 3 and ranged from 151.6 to $159.8,130.0$ to 133.7 , and 109.7 to 111.9 for $\mathrm{MH}, \mathrm{MC}$, and $\mathrm{ML}$, respectively, in generation 42 . In generation 51, heat loss means ranged from 159.7 to $172.9,123.1$ to 130.1 , and 93.6 to 97.3 for $\mathrm{MH}$, $\mathrm{MC}$, and ML, respectively. When selection was resumed at generation 42 , the difference in heat loss (kcal$\mathrm{kg}^{-0.75} \cdot \mathrm{d}^{-1}$ ) between the $\mathrm{MH}$ and $\mathrm{ML}$ lines averaged $34.4 \%$ as a percentage of the MC mean. By generation 51 , this difference averaged $55.7 \%$. After the original 15 generations of selection, divergence was $53.6 \%$, as a percentage of the $\mathrm{MC}$, between the $\mathrm{MH}$ and ML lines.

During the 26 generations of relaxed selection, response achieved in the ML during the initial 16 generations of selection was maintained; the $\mathrm{ML}$ and $\mathrm{MC}$ means for heat loss were essentially the same when selection was renewed as when selection had ceased. However, response achieved in $\mathrm{MH}$ selection was partially lost during the 26 generations of relaxed selection. About $40 \%$ of the response that had been achieved in the up direction was lost, presumably due to natural selection, to unintended selection for some other characteristic, or from breakup of linkages (recombination losses) that had been enhanced or built up during the initial selection phase. The latter possibilities seem less likely because we expanded line size during the relaxed phase so that inbreeding accumulated at less than $0.5 \%$ per generation and because we did not see a similar loss of response in the low direction. The $\mathrm{MH}$ mice react 
Table 2. Regressions of line cumulative selection differential (CSD) and standardized CSD on generation number (gen), divergence of the response $\left(\mathrm{kcal}^{\mathrm{kg}} \mathrm{kg}^{-0.75} \cdot \mathrm{d}^{-1}\right)$ on generation number

\begin{tabular}{|c|c|c|c|c|}
\hline Regression ${ }^{1}$ & Replicate 1 & Replicate 2 & Replicate 3 & $\begin{array}{c}\text { Mean across } \\
\text { replicates }\end{array}$ \\
\hline MH CSD on gen & 11.66 & 10.57 & 12.22 & $11.48 \pm 0.49$ \\
\hline ML CSD on gen & -6.72 & -6.59 & -6.92 & $-6.74 \pm 0.10$ \\
\hline MH standard CSD on gen & 0.67 & 0.69 & 0.65 & $0.67 \pm 0.01$ \\
\hline ML standard CSD on gen & -0.61 & -0.66 & -0.62 & $-0.63 \pm 0.02$ \\
\hline $\mathrm{MH}-\mathrm{ML}$ on gen & 2.12 & 2.27 & 3.07 & $2.49 \pm 0.30$ \\
\hline $\mathrm{MH}-\mathrm{ML}$ on CSD & 0.11 & 0.13 & 0.16 & $0.14 \pm 0.01$ \\
\hline $\mathrm{MH}-\mathrm{MC}$ on CSD & 0.07 & 0.14 & 0.25 & $0.16 \pm 0.05$ \\
\hline $\mathrm{ML}-\mathrm{MC}$ on CSD & 0.18 & 0.05 & -0.02 & $0.07 \pm 0.06$ \\
\hline
\end{tabular}

${ }^{1} \mathrm{MH}$ CSD on gen $=$ regression of high heat loss CSD on generation number; $\mathrm{ML}$ CSD on gen = regression of low heat loss CSD on generation number; MH standard on gen = regression of $\mathrm{MH}$ standardized CSD on generation number; ML standard on gen = regression of ML standardized CSD on generation number; $\mathrm{MH}-\mathrm{ML}$ on gen = regression of divergence of selection response on generation number; $\mathrm{MH}-\mathrm{ML}$ on CSD = regression of divergence of selection response on divergence of CSD; MH - MC on CSD = regression of selection response in the upward direction on difference of $\mathrm{MH}$ and $\mathrm{MC}$ CSD; and $\mathrm{ML}-\mathrm{MC}=$ regression of selection response in the downward direction on difference of ML and MC CSD.

more strongly to stressors with greater corticosterone production (Y. Zhou, University of Nebraska, Lincoln, personal communication); thus, mice in this line may be affected more by natural selection. Nonetheless, loss of $40 \%$ of the response during the relaxed selection phase seems large.

Regressions of divergence of response (MH - ML) on generation number are listed in Table 2. Regressions of divergence of response and responses in the upward and downward directions $\mathrm{MH}-\mathrm{MC}$ and $\mathrm{ML}-\mathrm{MC}$, respectively) on difference in realized cumulative selection differentials are also listed in Table 2 . The average change in heat loss per generation was calculated by regressing divergence of response on generation number. These estimates ranged from 2.12 to 3.07 and averaged $2.49 \pm 0.30 \mathrm{kcal} \cdot \mathrm{kg}^{-0.75} \cdot \mathrm{d}^{-1}$ for the 3 replicates. During the original selection, Nielsen et al. (1997a) observed an average divergence of $4.70 \pm 0.09$.

Heritability estimates were calculated by regressing divergence of response on the difference (MH - ML) in realized cumulative selection differentials. Realized heritability estimates ranged from 0.11 to 0.16 and averaged $0.14 \pm 0.01$ (Table 2). These estimates are lower than the regression estimates reported by Nielsen et al. (1997a) for the first 15 generations of selection. They observed an average realized heritability estimate of $0.28 \pm 0.003$. The difference in realized heritability estimates between the original and renewed selection is reflected by the lack of response in the ML lines in later generations. For generations 42 through 46 , realized heritability, based on divergence, ranged from 0.23 to 0.29 and averaged $0.25 \pm 0.02$ across the 3 replicates, which was comparable to the estimates obtained during the original selection.

Heritability estimates for response in the upward and downward directions were calculated by regressing the average difference in heat loss $\left(\mathrm{kcal} \cdot \mathrm{kg}^{-0.75} \cdot \mathrm{d}^{-1}\right)$ for $\mathrm{MH}$ $-\mathrm{MC}$ and $\mathrm{ML}-\mathrm{MC}$ on the difference in realized cumula- tive selection differentials. The regression estimates for increased heat loss ranged from 0.07 to 0.25 and averaged $0.16 \pm 0.05$ for all replicates (Table 2). The estimates for decreased heat loss ranged from -0.02 to 0.18 and averaged $0.07 \pm 0.06$. Estimates reported here were much lower than those obtained by Nielsen et al. (1997a) for all 3 replicates of $\mathrm{MH}$ selection. They observed that the regression of response in the upward direction on selection differential ranged from 0.28 to 0.33. Also, Nielsen et al. (1997a) reported that regressions of response in the downward direction on selection differential ranged from 0.23 to 0.26 , which is close to the estimate of 0.18 in replicate 1 , but much greater than the estimates of replicates 2 and 3.

\section{Response in Feed Intake}

Means for feed intake adjusted for metabolic size of male mice between the ages of 8 and $11 \mathrm{wk}$ are listed

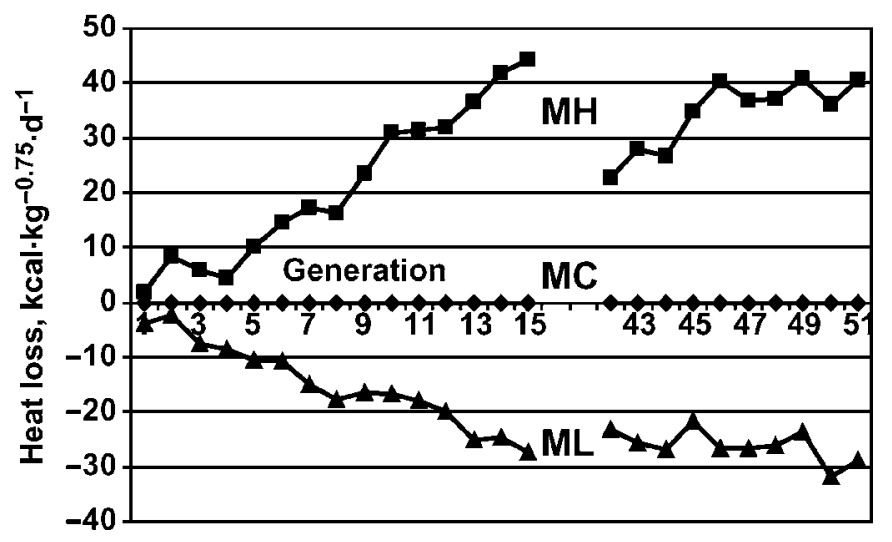

Figure 1. Line $(\mathrm{MH}=$ high; $\mathrm{ML}=$ low ; and $\mathrm{MC}=$ control, set to zero) means for heat loss $\left(\mathrm{kcal} \cdot \mathrm{kg}^{-0.75} \cdot \mathrm{d}^{-1}\right)$ averaged across all 3 replicates of selection. Selection ceased between generations 16 and 42 and then was renewed. 
Table 3. Means for heat loss $\left(\mathrm{kcal} \cdot \mathrm{kg}^{-0.75} \cdot \mathrm{d}^{-1}\right)$ in 3 replicates during 9 generations of renewed selection ${ }^{1}$

\begin{tabular}{|c|c|c|c|c|c|c|c|c|c|c|c|c|}
\hline \multirow[b]{2}{*}{ Generation } & \multicolumn{3}{|c|}{ Replicate 1} & \multicolumn{3}{|c|}{ Replicate 2} & \multicolumn{3}{|c|}{ Replicate 3} & \multicolumn{3}{|c|}{ Mean across replicates } \\
\hline & MH & $\mathrm{MC}$ & ML & MH & $\mathrm{MC}$ & ML & $\mathrm{MH}$ & $\mathrm{MC}$ & ML & MH & $\mathrm{MC}$ & ML \\
\hline 42 & 159.8 & 133.7 & 111.9 & 155.8 & 135.2 & 109.7 & 151.6 & 130.0 & 108.2 & 155.7 & 133.0 & 109.9 \\
\hline 43 & 155.9 & 136.3 & 107.2 & 169.0 & 137.9 & 105.0 & 157.9 & 125.1 & 110.6 & 160.9 & 133.1 & 107.6 \\
\hline 44 & 165.7 & 140.5 & 112.7 & 163.5 & 127.5 & 105.4 & 158.8 & 140.2 & 109.2 & 162.7 & 136.1 & 109.1 \\
\hline 45 & 165.7 & 129.1 & 110.3 & 165.5 & 126.3 & 105.0 & 163.0 & 133.9 & 108.9 & 164.7 & 129.8 & 108.1 \\
\hline 46 & 173.8 & 138.7 & 109.0 & 173.2 & 131.3 & 104.6 & 175.0 & 131.2 & 107.7 & 174.0 & 133.7 & 107.1 \\
\hline 47 & 168.8 & 135.6 & 107.8 & 167.6 & 132.1 & 101.2 & 166.0 & 124.3 & 103.0 & 167.5 & 130.7 & 104.0 \\
\hline 48 & 159.9 & 125.1 & 101.1 & 166.5 & 130.0 & 98.9 & 161.9 & 121.6 & 98.1 & 162.8 & 125.6 & 99.4 \\
\hline 49 & 160.5 & 133.5 & 95.2 & 154.3 & 105.0 & 90.6 & 159.9 & 113.8 & 95.6 & 158.2 & 117.4 & 93.8 \\
\hline 50 & 160.7 & 130.5 & 97.7 & 163.1 & 129.4 & 89.0 & 159.5 & 114.7 & 92.2 & 161.1 & 124.9 & 93.0 \\
\hline 51 & 172.9 & 130.1 & 95.8 & 162.0 & 123.1 & 93.6 & 159.7 & 119.8 & 97.3 & 164.9 & 124.3 & 95.6 \\
\hline
\end{tabular}

${ }^{1} \mathrm{MH}=$ High heat loss selection; ML = low heat loss selection; and MC = no intentional selection.

in Table 4. Line averages in the 3 replicates ranged from 72.0 to $79.0,65.1$ to 69.5 , and 55.2 to $59.1 \mathrm{~g}$. $\mathrm{kg}^{-0.75} \cdot \mathrm{d}^{-1}$ for $\mathrm{MH}, \mathrm{MC}$, and ML, respectively. Regressions of response in feed intake on generation number are listed in Table 5. Average regressions of $\mathrm{MH}-\mathrm{ML}$, $\mathrm{MH}-\mathrm{MC}$, and $\mathrm{ML}-\mathrm{MC}$ were $0.79 \pm 0.28,0.84 \pm$ 0.27 , and $0.05 \pm 0.01$, respectively. By generation 51 , divergence of $\mathrm{MH}$ and $\mathrm{ML}$ males in feed intake per unit metabolic size was $34.0 \%$ of the MC mean. This is greater than the difference of $20.6 \%$ at generation 15 that was observed by Nielsen et al. (1997b). At the end of selection, reduction in feed intake in the low direction was approximately $15 \%$ of the control mean. Although part of the response in heat loss in the upward direction $(\mathrm{MH})$ was lost during the generations of relaxed selection; the same was not true in the response achieved in feed intake. When selection resumed (generation 42), divergence of $\mathrm{MH}$ from $\mathrm{ML}$ relative to $\mathrm{MC}$ mice (21.5\%) for feed intake was at least as great as had been measured at generation 15 .

Sharp et al. (1984) investigated responses in several lines of mice, which included lines selected for high and low feed intake. They found that the high and low feed intake lines diverged by $17 \%$ of the control mean and had a heritability estimate of 0.15 . This estimate of heritability was for the entire feed intake of growing animals and consisted of maintenance and growth components. Bishop and Hill (1985) and Selman et al. (2001) confirmed these results by conducting related studies with the same lines of mice in Scotland.

Sutherland et al. (1970) selected mice on increased efficiency of feed usage (gain/feed), increased feed intake, and increased rate of gain. They observed heritability estimates of $0.17 \pm 0.04$ for the overall gain:feed ratio estimate and $0.20 \pm 0.06$ for feed intake. Comparison of results between Sutherland et al. (1970) and this study are difficult due to differences in traits measured.

Residual feed intake is defined as the difference between actual feed intake and predicted feed intake, the latter based on BW maintained and gain (Koch et al., 1963). Variation in residual intake is most likely due to variation in the partial efficiency coefficient for maintenance requirement, assuming the partial efficiency coefficient for growth is constant. One might then expect that heritability of residual feed intake would be similar to heritability for heat loss for animals that are growing very little. Jensen et al. (1992) estimated residual energy intake in Holstein Friesian and Brown

Table 4. Means for feed intake $\left(\mathrm{g} \cdot \mathrm{kg}^{-0.75} \cdot \mathrm{d}^{-1}\right)$ of male mice measured over a 21 -d period between the ages of 8 and 11 wk in 3 replicates $^{1}$

\begin{tabular}{|c|c|c|c|c|c|c|c|c|c|c|c|c|}
\hline \multirow[b]{2}{*}{ Generation } & \multicolumn{3}{|c|}{ Replicate 1} & \multicolumn{3}{|c|}{ Replicate 2} & \multicolumn{3}{|c|}{ Replicate 3} & \multicolumn{3}{|c|}{ Mean across replicates } \\
\hline & $\mathrm{MH}$ & $\mathrm{MC}$ & ML & $\mathrm{MH}$ & $\mathrm{MC}$ & ML & $\mathrm{MH}$ & $\mathrm{MC}$ & ML & $\mathrm{MH}$ & $\mathrm{MC}$ & ML \\
\hline 42 & 72.7 & 72.1 & 57.8 & 72.9 & 66.9 & 56.9 & 70.5 & 67.4 & 56.9 & 72.0 & 68.8 & 57.2 \\
\hline 43 & 76.3 & 70.8 & 62.1 & 75.9 & 68.9 & 57.3 & 70.4 & 66.8 & 57.8 & 74.2 & 68.8 & 59.1 \\
\hline 44 & 75.6 & 72.6 & 58.7 & 74.4 & 66.1 & 56.5 & 70.2 & 64.1 & 56.6 & 73.4 & 67.6 & 57.3 \\
\hline 45 & 73.8 & 66.4 & 58.5 & 72.3 & 63.7 & 55.7 & 72.5 & 65.2 & 54.4 & 72.9 & 65.1 & 56.2 \\
\hline 46 & 77.4 & 68.6 & 57.0 & 76.1 & 65.3 & 54.4 & 74.5 & 66.5 & 59.7 & 76.0 & 66.8 & 57.0 \\
\hline 47 & 80.7 & 69.6 & 60.3 & 73.4 & 66.2 & 56.6 & 72.4 & 64.9 & 53.8 & 75.5 & 66.9 & 56.9 \\
\hline 48 & 76.3 & 68.7 & 56.8 & 71.6 & 63.7 & 53.6 & 75.1 & 64.5 & 55.2 & 74.3 & 65.6 & 55.2 \\
\hline 49 & 75.4 & 67.6 & 55.8 & 71.6 & 63.5 & 54.3 & 77.7 & 65.4 & 57.4 & 74.9 & 65.5 & 55.8 \\
\hline 50 & 81.4 & 76.4 & 61.9 & 76.8 & 65.5 & 55.0 & 78.9 & 66.7 & 56.2 & 79.0 & 69.5 & 57.7 \\
\hline 51 & 84.1 & 66.8 & 57.3 & 73.9 & 64.8 & 55.6 & 77.1 & 64.0 & 55.7 & 78.4 & 65.2 & 56.2 \\
\hline
\end{tabular}

${ }^{1} \mathrm{MH}=$ High heat loss selection; $\mathrm{ML}=$ low heat loss selection; and $\mathrm{MC}=$ no intentional selection. 
Table 5. Regressions of the response in feed intake ( $\mathrm{g}$. $\mathrm{kg}^{-0.75} \cdot \mathrm{d}^{-1}$ ) on generation number for each replicate, and averages and SE across replicates

\begin{tabular}{lcccc}
\hline \hline Regression $^{1}$ & Replicate 1 & Replicate 2 & Replicate 3 & Mean \\
\hline MH - ML & 1.03 & 0.24 & 1.11 & $0.79 \pm 0.28$ \\
MH - MC & 1.05 & 0.31 & 1.16 & $0.84 \pm 0.27$ \\
ML - MC & 0.02 & 0.07 & 0.04 & $0.05 \pm 0.01$ \\
\hline
\end{tabular}

${ }^{1} \mathrm{MH}-\mathrm{ML}=$ Regression of divergence of $\mathrm{MH}$ and $\mathrm{ML}$ feed intake on generation number; $\mathrm{MH}-\mathrm{MC}=$ regression of response in the upward direction on generation number; and $\mathrm{ML}-\mathrm{MC}=$ regression of response in the downward direction on generation number.

Swiss bulls. The heritability estimate of 0.30 that they reported for residual energy intake was similar to our estimate of 0.28 for heat loss during the initial 15 generations of selection. Fan et al. (1995) derived estimates of residual feed intake and observed a genetic correlation between actual daily energy intake and residual energy intake of 0.89. Luiting and Urff (1991) worked with White Leghorn laying hens and demonstrated that repeatability of residual feed intake estimates was between 0.52 and 0.58. Jensen et al. (1992) and Luiting and Urff (1991) predicted individual feed intake from regression equations derived from their data, whereas Fan et al. (1995) predicted individual feed intake from standard energy equations.

\section{Response in Male BW}

Means for male BW at time of heat loss measurement in 3 replicates during 9 generations of renewed selection are given in Table 6. Means ranged from 31.4 to 32.6 $\mathrm{g}$ for $\mathrm{MH}, 33.7$ to $36.5 \mathrm{~g}$ for $\mathrm{MC}$, and 30.5 to $34.1 \mathrm{~g}$ in ML. Regressions of divergence of male BW on generation number are available in Table 7 . The average regression of divergence of $\mathrm{MH}$ and $\mathrm{ML}$ male BW on generation number was $0.33 \pm 0.13$, which is much greater than the estimate $(-0.04 \pm 0.10)$ found by Nielsen et al. (1997b) over the first 15 generations. The average regressions of $\mathrm{MH}-\mathrm{MC}$ and $\mathrm{ML}-\mathrm{MC}$ on generation number were $0.04 \pm 0.11$ and $-0.28 \pm 0.23$, respectively.
Table 7. Regressions of divergence in male BW on generation number, averages across replicates and SE

\begin{tabular}{lcccr}
\hline \hline Regression $^{1}$ & Replicate 1 & Replicate 2 & Replicate 3 & Average \pm SE \\
\hline MH - ML & 0.58 & 0.19 & 0.21 & $0.33 \pm 0.13$ \\
MH - MC & -0.17 & 0.09 & 0.20 & $0.04 \pm 0.11$ \\
ML - MC & -0.75 & -0.10 & -0.01 & $-0.28 \pm 0.23$ \\
\hline
\end{tabular}

${ }^{1} \mathrm{MH}-\mathrm{ML}=$ Regression of divergence of response in male BW on generation number; $\mathrm{MH}-\mathrm{MC}=$ regression of the difference in $\mathrm{BW}$ between the high heat loss and control lines on generation number; and $\mathrm{ML}-\mathrm{MC}=$ regression of the difference in $\mathrm{BW}$ between the low heat loss and control lines on generation number.

Regressions of weight differences on generation number suggest that selection for lower heat loss and less feed intake per unit size, and thus greater efficiency, in the ML line resulted in decreased BW when compared with the MC mean. This result is different than what was found by Nielsen et al. (1997b). They did not observe a noticeable trend in BW of males over 15 generations of selection in the $\mathrm{MH}, \mathrm{MC}$, and $\mathrm{ML}$ lines. Analysis of average BW showed that the $\mathrm{MC}$ mice were on average $2.86 \pm 0.12 \mathrm{~g}$ heavier than the $\mathrm{MH}$ mice $(P$ $<0.01)$ and $3.10 \pm 0.12 \mathrm{~g}$ heavier than the ML mice $(P$ $<0.01$ ). Thus far, all of the observed traits within these lines have seemed to diverge with selection. However, male BW decreased in both of the selection lines when compared with the control. This suggests that there must be 2 separate mechanisms controlling $\mathrm{BW}$ of $\mathrm{MH}$ and ML mice relative to MC mice.

During the initial generations of selection, no correlated selection occurred for BW (regressions of CSD for $\mathrm{BW}$ on generation number averaged 0.02 and $0.04 \mathrm{~g}$ for $\mathrm{MH}$ and ML, respectively). During the renewed selection, no correlated selection was applied for $\mathrm{MH}$ (average $=0.05 \mathrm{~g}$ per generation), but some unintentional selection was applied for ML $(-0.50 \pm 0.03 \mathrm{~g}$ per generation). With heat loss arising from energy used for maintenance and from the inefficiency of energy used for gain, and given that mice at this measurement age still experience some growth, this could explain part of the limited negative selection on body size and the resulting

Table 6. Means for male weight (g) at the time of heat loss measurement in 3 replicates during 9 generations of selection ${ }^{1}$

\begin{tabular}{|c|c|c|c|c|c|c|c|c|c|c|c|c|}
\hline \multirow[b]{2}{*}{ Generation } & \multicolumn{3}{|c|}{ Replicate 1} & \multicolumn{3}{|c|}{ Replicate 2} & \multicolumn{3}{|c|}{ Replicate 3} & \multicolumn{3}{|c|}{ Mean across replicates } \\
\hline & $\mathrm{MH}$ & $\mathrm{MC}$ & ML & $\mathrm{MH}$ & $\mathrm{MC}$ & ML & $\mathrm{MH}$ & $\mathrm{MC}$ & ML & $\mathrm{MH}$ & $\mathrm{MC}$ & ML \\
\hline 42 & 34.5 & 35.2 & 37.0 & 30.8 & 37.8 & 32.5 & 29.8 & 36.6 & 32.9 & 31.7 & 36.5 & 34.1 \\
\hline 43 & 35.0 & 33.8 & 35.4 & 31.9 & 36.7 & 32.4 & 30.1 & 34.3 & 32.3 & 32.3 & 34.9 & 33.4 \\
\hline 44 & 36.6 & 33.2 & 34.8 & 30.8 & 34.5 & 32.4 & 29.5 & 33.5 & 31.4 & 32.3 & 33.7 & 32.9 \\
\hline 45 & 35.3 & 33.6 & 34.2 & 31.2 & 35.3 & 32.3 & 30.2 & 34.8 & 31.5 & 32.2 & 34.6 & 32.7 \\
\hline 46 & 35.7 & 35.5 & 34.5 & 30.5 & 35.5 & 32.4 & 29.1 & 33.9 & 30.4 & 31.8 & 35.0 & 32.4 \\
\hline 47 & 35.3 & 34.7 & 34.4 & 31.2 & 35.5 & 31.3 & 30.0 & 33.9 & 30.2 & 32.2 & 34.7 & 32.0 \\
\hline 48 & 34.9 & 33.9 & 30.9 & 31.2 & 35.5 & 31.3 & 30.5 & 33.5 & 29.5 & 32.2 & 34.7 & 30.5 \\
\hline 49 & 34.6 & 36.1 & 30.9 & 30.3 & 35.3 & 31.0 & 29.2 & 33.6 & 29.8 & 31.4 & 35.0 & 30.6 \\
\hline 50 & 36.4 & 35.3 & 32.2 & 31.4 & 36.5 & 31.0 & 29.9 & 33.8 & 31.6 & 32.6 & 35.2 & 31.6 \\
\hline 51 & 35.9 & 36.7 & 33.4 & 30.4 & 34.4 & 30.4 & 29.1 & 32.8 & 30.3 & 31.8 & 34.6 & 31.4 \\
\hline
\end{tabular}

${ }^{1} \mathrm{MH}=$ High heat loss selection; $\mathrm{ML}=$ low heat loss selection; and $\mathrm{MC}=$ no intentional selection. 
response. As noted previously, $\mathrm{MH}$ mice express greater response to stress. The MH mice are more active (Mousel et al., 2001) and also have less body fat than the MC and ML lines (Moody et al., 1997; Nielsen et al., 1997b). The difference in body fat between the MH and MC mice amounts to over $1.0 \mathrm{~g}$. Thus, part of the smaller $\mathrm{BW}$ of the $\mathrm{MH}$ mice is due to indirect selection responses in body fatness.

Sutherland et al. (1970) found that mouse lines that were previously selected for greater efficiency of gain (gain:feed ratio) had greater rates of gain than lines selected solely on greater feed intake. They also showed that rate of gain had a high positive correlation (0.91 \pm 0.04 ) with gain:feed ratio. Sharp et al. (1984) selected mice based on appetite, percent fat, or percent lean tissue. Their findings were that mice in the high appetite line were heavier at any age but had greater gain:feed ratios. In related studies, Bishop and Hill (1985) and Selman et al. (2001) used the same selection lines of mice as Sharp et al. (1984), and in all of these studies, lines of mice selected for greater gain had responses in gain:feed ratio similar to the response achieved in our ML line.

The selection practices of Sutherland et al. (1970), Sharp et al. (1984), Bishop and Hill (1985), and Selman et al. (2001) have focused on increasing efficiency through increases in gain, which would ultimately result in mathematically greater efficiency (Equation 1). In these cases, partial efficiencies for maintenance and growth may or may not be changed. These methods are slightly different than our method of selection, which focuses on changing the partial efficiency coefficient associated with the maintenance energy requirement component of feed intake. Eggert and Nielsen (2006) reported no evidence that divergent selection for heat loss in mice changed the costs of deposition of fat and lean tissues associated with growth. Selection only affected the partial efficiency of maintenance per unit size.

Pym and Nicholls (1979) investigated direct and correlated responses to selection for lower feed conversion ratios calculated as feed:gain ratio (the inverse of equation 1), increased gain, or increased intake in broiler chickens. They found that weight gains increased in all 3 of the selection lines and observed a realized heritability estimate of $0.37 \pm 0.04$ for BW gain. However, this estimate reflects the heritability of only the gain component of efficiency.

Kownacki et al. (1975) studied the effects of selection for postweaning growth rate on basal metabolic rate in mice. Their findings were that the postweaning growth rate of a mouse was inversely related to its basal metabolic rate. Therefore, mice with low basal metabolic rates will have greater gains and thus greater mathematical efficiency. In a related study, Kownacki and Keller (1978) confirmed that selection for postweaning gain is related to a physiological mechanism that influences basal metabolic rates by showing that mice selected for high postweaning growth rates had basal metabolic rates that were, on average, $8.5 \%$ lower than those of the unselected control group.

Rios et al. (1986) worked with lines of rats that had been previously selected for high or low 3 to 9 wk gain. They observed that rats selected for lesser gains had a $3 \%$ decrease in average daily intake when compared with controls. They were also able to obtain estimates of heat loss for rats in these lines. Rios et al. (1986) found that rats in the low 3 to 9 wk gain line had $1 \%$ lower heat loss estimates when compared with the control mean. These results are consistent with the current study in that selection for reduced heat loss has produced male mice that consume less feed and have reduced $\mathrm{BW}$ when compared with the control lines.

\section{Effects of Selection on Litter Size and Conception Rate}

Mean litter sizes per generation-line are presented in Table 8. Least-squares means were $12.0 \pm 0.23,11.6$ \pm 0.20 , and $10.4 \pm 0.26$ for $\mathrm{MH}, \mathrm{MC}$, and $\mathrm{ML}$, respectively. The ML dams produced, on average, 1.6 fewer pups than $\mathrm{MH}$ dams $(P=0.05)$. The test for selection response was significant $(P<0.05)$, and there was no evidence for asymmetry of selection response $(P=0.41)$. These results are similar to what was observed by Nielsen et al. (1997b), except that the difference between the $\mathrm{MH}$ and $\mathrm{ML}$ lines was more significant after generation 15 than in the recent generations. As in the earlier report, MH dams produced more pups than ML dams, and MC dams were intermediate for litter size born. Nielsen et al. (1997b) demonstrated that differences among the lines in litter size were due to differences in ovulation rate.

Conception rate was calculated as the number of females that produced litters divided by the number of females exposed to males in breeding cages. Average conception rates for each generation-line are presented in Table 8. The ML dams, on average, had a 6.7\% greater conception rate than $\mathrm{MH}$ dams. The test for selection response (MH vs. ML) tended toward significance $(P=0.08)$; there was no evidence for asymmetry of selection response $(P=0.24)$. Kgwatalala et al. (2004) measured conception rate using these same heat loss lines of mice in normal, hot, and cold environments. They did not observe any differences in conception rate due to line or environment $\times$ line interaction.

\section{IMPLICATIONS}

Several generations of relaxed selection for reduced heat loss, and hence reduced feed intake, were not characterized by loss of response. Additional response in feed intake through renewed selection to reduce heat loss was difficult to attain. Reduction in feed intake, attained through reduction in maintenance requirements, was approximately 15\%. Litter size was reduced, but conception rate was not affected, when selec- 
Table 8. Means for litter size at first parity and conception rate averaged across 3 replicates during 9 generations of selection

\begin{tabular}{|c|c|c|c|c|c|c|}
\hline \multirow[b]{3}{*}{ Generation } & \multicolumn{6}{|c|}{$\operatorname{Line}^{1}$} \\
\hline & \multicolumn{2}{|c|}{$\mathrm{MH}$} & \multicolumn{2}{|c|}{$\mathrm{MC}$} & \multicolumn{2}{|c|}{ ML } \\
\hline & $\begin{array}{l}\text { Litter } \\
\text { size }\end{array}$ & $\begin{array}{l}\text { Conception } \\
\text { rate }\end{array}$ & $\begin{array}{l}\text { Litter } \\
\text { size }\end{array}$ & $\begin{array}{c}\text { Conception } \\
\text { rate }\end{array}$ & $\begin{array}{l}\text { Litter } \\
\text { size }\end{array}$ & $\begin{array}{c}\text { Conception } \\
\text { rate }\end{array}$ \\
\hline 42 & 11.5 & 86.7 & 11.9 & 97.2 & 10.3 & 95.3 \\
\hline 43 & 12.4 & 88.0 & 11.4 & 95.1 & 11.3 & 91.5 \\
\hline 44 & 11.7 & 84.3 & 11.7 & 94.2 & 10.9 & 87.9 \\
\hline 45 & 11.7 & 89.8 & 11.1 & 97.1 & 10.7 & 98.1 \\
\hline 46 & 12.0 & 89.8 & 11.5 & 85.2 & 10.1 & 92.4 \\
\hline 47 & 12.7 & 93.5 & 11.7 & 92.2 & 10.4 & 93.5 \\
\hline 48 & 11.7 & 75.9 & 12.2 & 92.2 & 10.0 & 94.4 \\
\hline 49 & 12.2 & 94.5 & 12.1 & 98.1 & 10.0 & 92.6 \\
\hline 50 & 12.1 & 83.3 & 11.7 & 95.6 & 10.1 & 97.2 \\
\hline 51 & 11.6 & 90.7 & 10.9 & 87.2 & 10.1 & 92.6 \\
\hline Average & $12.0 \pm 0.23$ & $87.6 \pm 1.9$ & $11.6 \pm 0.20$ & $93.7 \pm 1.9$ & $10.4 \pm 0.26$ & $93.5 \pm 1.9$ \\
\hline
\end{tabular}

${ }^{1} \mathrm{MH}=$ High heat loss selection; ML = low heat loss selection; and MC = no intentional selection.

tion was practiced to reduce feed intake. Thus, selection to reduce feed intake in livestock species should be possible, but some aspects of reproduction could be adversely affected.

\section{LITERATURE CITED}

Bishop, S. C., and W. G. Hill. 1985. Effects of selection on growth, body composition, and food intake in mice: iii. Correlated responses: Growth, body composition, food intake, and efficiency and catabolism. Gen. Res. 46:57-74.

Eggert, D. L., and M. K. Nielsen. 2006. Costs of lean deposition, fat deposition and maintenance in three lines of mice selected for heat loss. J. Anim. Sci. 84:276-282.

Fan, L. Q., D. R. C. Bailey, and N. H. Shannon. 1995. Genetic parameter estimation of postweaning gain, feed intake, and feed efficiency for Hereford and Angus bulls fed two different diets. J. Anim. Sci. 73:365-372.

Jensen, J., I. L. Mao, B. Bech Andersen, and P. Madsen. 1992. Phenotypic and genetic relationships between residual energy intake and growth, feed intake, and carcass traits of young bulls. J. Anim. Sci. 70:386-395.

Kgwatalala, P. M., J. L. DeRoin, and M. K. Nielsen. 2004. Performance of mice lines divergently selected for heat loss when exposed to different environmental temperatures. I. Reproductive performance, pup survival and metabolic hormones. J. Anim. Sci. 82:2876-2883.

Koch, R. M., L. A. Swiger, D. Chambers, and K. E. Gregory. 1963. Efficiency of feed use in beef cattle. J. Anim. Sci. 22:486-494.

Kownacki, M., and J. Keller. 1978. The basal metabolic rate in selected and unselected mice. Gen. Pol. 19:339-344.

Kownacki, M., J. Keller, and E. Gebler. 1975. Selection of mice for high weight gains- it's effect on the basal metabolic rate. Gen. Pol. 16:359-363.

Luiting, P., and E. M. Urff. 1991. Residual feed consumption in laying hens. 1. Quantification of phenotypic variation and repeatabilities. Poult. Sci. 70:1655-1662.
McDonald, J. M., and M. K. Nielsen. 2006. Correlated responses in maternal performance following divergent selection for heat loss in mice. J. Anim. Sci. 84:3000-3004.

Moody, D. E., D. Pomp, and M. K. Nielsen. 1997. Variability in metabolic rate, feed intake and fatness among selection and inbred lines of mice. Genet. Res. Camb. 70:225-235.

Mousel, M. R., W. W. Stroup, and M. K. Nielsen. 2001. Locomotor activity, core body temperature and circadian rhythms in mice selected for high or low heat loss. J. Anim. Sci. 79:861-868.

Nielsen, M. K., B. A. Freking, L. D. Jones, S. M. Nelson, T. L. Vordorstrasse, and B. A. Hussey. 1997b. Divergent selection for heat loss in mice: II. Correlated responses in feed intake, body mass, body composition, and number born through fifteen generations. J. Anim. Sci. 75:1469-1476.

Nielsen, M. K., L. D. Jones, B. A. Freking, and J. A. DeShazer. 1997a. Divergent selection for heat loss in mice: I. Selection applied and direct response through fifteen generations. J. Anim. Sci. 75:1461-1468.

Pym, R. A. E., and P. J. Nicholls. 1979. Selection for food conversion in broilers: Direct and correlated responses to selection for bodyweight gain, food consumption and food conversion ratio. $\mathrm{Br}$. Poult. Sci. 20:73-86.

Rios, J. G., M. K. Nielsen, G. E. Dickerson, and J. A. DeShazer. 1986. Selection for postweaning gain in rats: i. Correlated responses in feed utilization and body composition. J. Anim. Sci. 63:34-45.

Selman, C., T. K. Korhonen, L. Bunger, W. G. Hill, and J. R. Speakman. 2001. Thermoregulatory responses of two mouse mus musculus strains selectively bred for high and low food intake. J. Comp. Physiol. [B] 171:661-668.

Shapiro, S. S., and M. B. Wilk. 1965. An analysis of variance test for normality and complete samples. Biometrika 52:592-611.

Sharp, G., W. G. Hill, and A. Robertson. 1984. Effects of selection on growth, body composition, and food intake in mice I. Responses in selected traits. Gen. Res. 43:75-92.

Sutherland, T. M., P. E. Biondini, L. H. Haverland, D. Pettus, and W. B. Owen. 1970. Selection for rate of gain, appetite and efficiency of feed utilization in mice. J. Anim. Sci. 31:1049-1057. 